\title{
Influence of Tillage Practices on Anthracnose Development and Distribution in Dry Bean Fields
}

\author{
N. Ntahimpera, H. R. Dillard, A. C. Cobb, and R. C. Seem, Department of Plant Pathology, Cornell University, \\ New York State Agricultural Experiment Station, Geneva 14456
}

\begin{abstract}
Ntahimpera, N., Dillard, H. R., Cobb, A. C., and Seem, R. C. 1997. Influence of tillage practices on anthracnose development and distribution in dry bean fields. Plant Dis. 81:71-76.

Three tillage practices—chiseling, rototilling, and moldboard plowing—were evaluated in 1993 and 1994 to determine their impact on initial disease development, distribution, and progression over time in a field of the susceptible kidney bean cultivar Horizon. The tillage treatments were administered in the spring in a field infested in 1992 with the bean anthracnose pathogen, Colletotrichum lindemuthianum race $\beta$. Initial disease incidence was highest in the chiseled plots, where more bean debris was left on the surface than in the other treatments. Significantly higher final disease incidence and area under the disease progress curve (AUDPC) occurred in the chiseled plots than in the rototilled and moldboard plowed plots. There was a significant correlation $(r=0.75)$ between the percentage of debris left on the surface and subsequent disease incidence on pods in the field. Anthracnose incidence or severity in the field was highly correlated with disease incidence on harvested pods ( $r$ values ranged between 0.87 and 0.98 ). Results from the ordinary runs analysis showed that anthracnose occurred randomly within the field early in the season, indicating that initial inoculum was from bean debris within the field. Later in the season, plant-to-plant spread resulted in a more clustered distribution of diseased plants.
\end{abstract}

Colletotrichum lindemuthianum (Sacc. \& Magnus) Lams.-Scrib., the causal agent of anthracnose on bea0n (Phaseolus vulgaris L.), is primarily a seedborne pathogen $(3,4,23,31)$. Control strategies include the use of disease-free seed, seed treatments, foliar fungicide applications, crop rotations, cultivars with race-specific resistance, and tillage methods $(1,17,31)$. Tillage refers to soil management practices before planting that aid in crop residue management and seed bed preparation. Tillage strategies include conventional or traditional deep tillage with moldboard plows that invert soil to depths of 20 to 30 $\mathrm{cm}$ and chiseling, which breaks up hard and compact soil layers with long narrow teeth (chisels) without inverting top horizons $(14,20,21)$.

In New York State, $C$. lindemuthianum is introduced to a production area on or in infested or infected seed. While the majority of growers purchase anthracnose-free certified seed, the disease remains a problem when certified seed of particular cultivars is unavailable or unaffordable $(2,9)$. The percentage of infected seed is an important determinant of the severity of bean anthracnose during the growing season

Corresponding author: N. Ntahimpera

E-mail: ntahimpera.1@osu.edu

Accepted for publication 9 October 1996.

Publication no. D-1996-1122-04R

(C) 1997 The American Phytopathological Society since the secondary inoculum produced will be proportional to the amount of initial inoculum. C. lindemuthianum can survive in bean crop residue, and crop rotations of 2 to 3 years are recommended to avoid the possibility of overwintered inoculum $(4,25)$. In areas where beans are consecutively cropped, overwintered inoculum can initiate epidemics of anthracnose (9).

Anthracnose conidia are spread from one plant to another by splashing raindrops (11). The average distance of conidia spread is 3 to $4.6 \mathrm{~m}$ per rainstorm of 10 $\mathrm{mm}$ or more (27). A 10-h wet period is necessary for $C$. lindemuthianum conidia to infect, and new lesions usually appear in 3 to 7 days (11). The pattern of disease incidence among adjacent plants in a field over time can be characterized using ordinary runs analysis $(7,8,10,13,29)$. If diseased plants in a row resulted from a pathogen spreading from plant to plant, one would expect an aggregation (clustering) of infected plants (13). Thus, there would be few runs, and the $Z$-statistic value would be a large negative number. However, if the pathogen was not spreading from plant to plant, one would expect a random mixing of healthy and infected plants and a corresponding large number of runs. The null hypothesis evaluated in this test is that the ordered sequence of infected plants is random. The alternative hypothesis is that the ordered sequence is clustered.

The objectives of this study were to determine the effect of tillage practices on initial disease levels and disease progres- sion over time and to investigate the pattern of initial anthracnose development and subsequent spread in infested fields. The tillage treatments-chiseling, rototilling, and plowing with a moldboard-were selected to represent different levels of residue incorporation. Preliminary results on portions of this work were previously reported (15).

\section{MATERIALS AND METHODS}

1993 experiment. The field site was located at the Fruit and Vegetable Research Farm of the New York State Agricultural Experiment Station (NYSAES), Geneva. Instruments used to collect weather data were located at the Climatological Reference Station operated by NYSAES in cooperation with the National Weather Service. Latitude is $42^{\circ} 53^{\prime} \mathrm{N}$, longitude $77^{\circ} 02^{\prime} \mathrm{W}$, and elevation $187 \mathrm{~m}$. The soil type is Lima silt loam with 0 to $3 \%$ slope and 2 to $6 \%$ organic matter content. The field was sown to beans in 1992, and the plants were inoculated with conidia of $C$. lindemuthianum race $\beta$. The selected tillage treatments were deep chiseling (chisel), which left infested bean debris from the previous crop near the soil surface; rototilling (rotary cultivator), which incorporated infested debris to a depth of $10 \mathrm{~cm}$; and moldboard plowing (moldboard plow), which incorporated infested debris to a depth of about $20 \mathrm{~cm}$. The treatments were arranged in a randomized complete block design with three replicates and administered on 4 June (prior to planting) using tractor-mounted implements. Individual plots were $40 \mathrm{~m}$ long and $7.6 \mathrm{~m}$ wide. On 4 June, eight rows ( $0.91 \mathrm{~m}$ apart) of certified bean seed cultivar Horizon (Asgrow Seed Co.) were planted into each plot at 26 to 30 seeds per $\mathrm{m}$. Planted seeds were pretreated with the fungicides captan and chloroneb to control soilborne pathogens, and the insecticide chlorpyrifos (Lorsban). Fertilizer (15-1515) was preplant broadcast, then incorporated at a rate of $337 \mathrm{~kg} / \mathrm{ha}$. The field was treated with the preemergence herbicides trifluralin (Treflan 4E, 1.4 liters/ha), EPTC (Eptam, 4.2 liters/ha), and metolachlor (Dual 8E, 0.85 liters/ha).

Prior to disease appearance, eight 1-m sections were randomly selected in each of the two central rows of each plot. Individual whole plants in each of the eight 1-m sections were evaluated for disease incidence and severity based on leaf and pod 


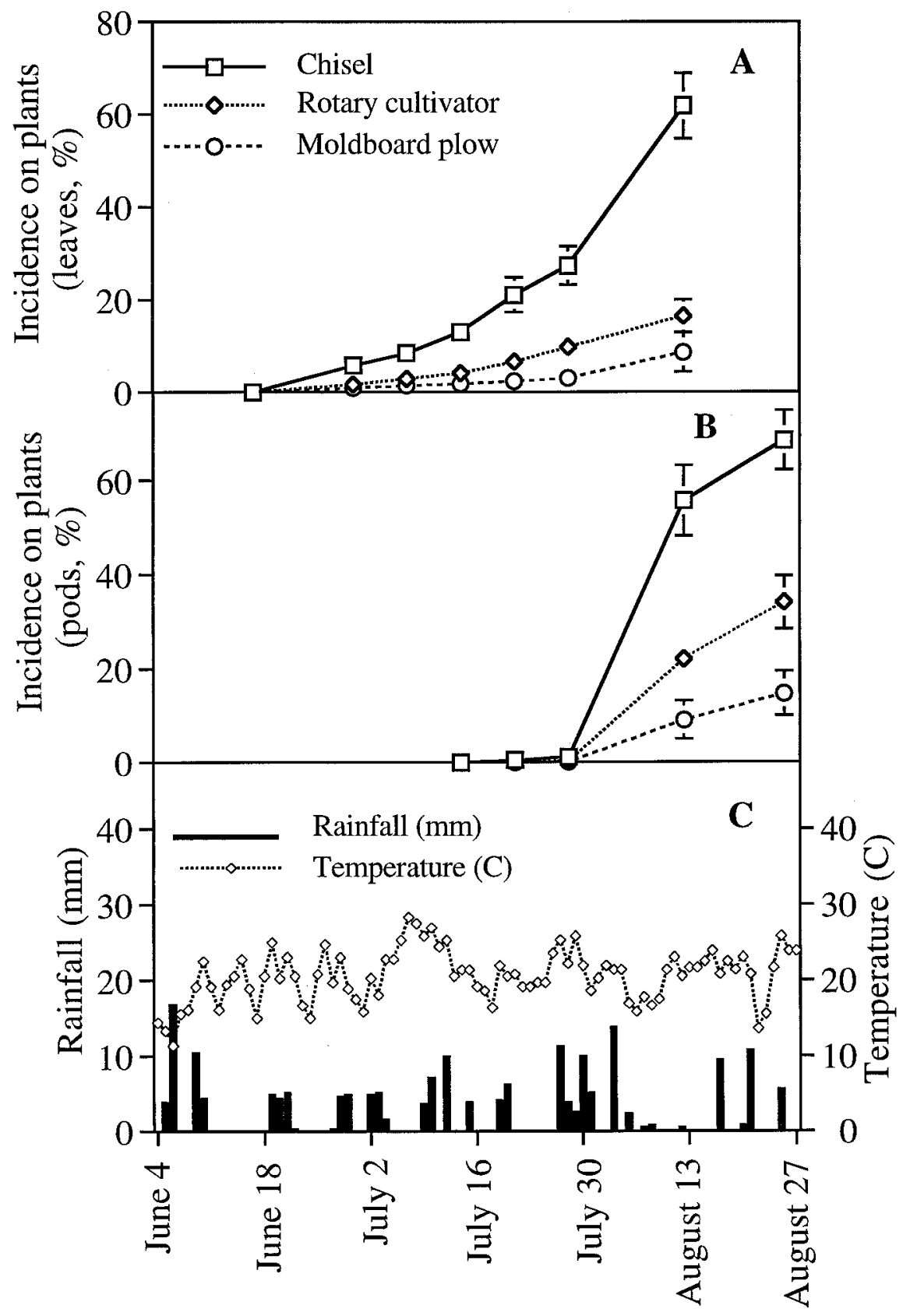

Fig. 1. Disease progress curves of bean anthracnose incidence on whole plants (A) based on leaf symptoms and (B) based on pod symptoms following spring tillage in 1993. Bars represent the standard error of the mean. (C) Daily precipitation and average temperature observed at the experimental site.

Table 1. Area under the disease progress curves (AUDPC) for bean anthracnose incidence and severity on whole plants based on leaf or pod symptoms, and disease incidence on harvested pods from different tillage treatments in 1993 and 1994

\begin{tabular}{|c|c|c|c|c|c|c|}
\hline \multirow[b]{3}{*}{ Year } & \multirow{3}{*}{$\begin{array}{l}\text { Tillage } \\
\text { treatments }\end{array}$} & \multicolumn{4}{|c|}{ AUDPC } & \multirow{3}{*}{$\begin{array}{l}\text { Incidence on } \\
\text { harvested pod }\end{array}$} \\
\hline & & \multicolumn{2}{|c|}{ Leaves } & \multicolumn{2}{|c|}{ Pods } & \\
\hline & & Incidence & Severity & Incidence & Severity & \\
\hline \multirow[t]{4}{*}{1993} & Chisel & $1,068.4 \mathrm{a}^{\mathrm{z}}$ & $30.4 \mathrm{a}$ & $1,276.1 \mathrm{a}$ & $112.1 \mathrm{a}$ & $52.0 \mathrm{a}$ \\
\hline & Rotary cultivator & $329.9 \mathrm{~b}$ & $12.8 \mathrm{~b}$ & $554.0 \mathrm{~b}$ & $56.9 \mathrm{~b}$ & $18.9 \mathrm{~b}$ \\
\hline & Moldboard plow & $139.8 \mathrm{~b}$ & $3.3 \mathrm{c}$ & $230.6 \mathrm{c}$ & $13.8 \mathrm{c}$ & $5.2 \mathrm{c}$ \\
\hline & $\operatorname{LSD}(P=0.05)$ & 220.9 & 4.0 & 98.5 & 15.2 & 6.6 \\
\hline \multirow[t]{4}{*}{1994} & Chisel & $453.1 \mathrm{a}$ & $14.0 \mathrm{a}$ & $424.2 \mathrm{a}$ & $37.3 \mathrm{a}$ & $47.1 \mathrm{a}$ \\
\hline & Rotary cultivator & $99.0 \mathrm{a}$ & $4.1 \mathrm{a}$ & $159.6 \mathrm{a}$ & $12.5 \mathrm{a}$ & $22.4 \mathrm{ab}$ \\
\hline & Moldboard plow & $41.4 \mathrm{a}$ & $0.8 \mathrm{a}$ & $56.0 \mathrm{a}$ & $2.7 \mathrm{a}$ & $6.7 \mathrm{~b}$ \\
\hline & $\operatorname{LSD}(P=0.05)$ & NS & NS & NS & NS & 34.2 \\
\hline
\end{tabular}

${ }^{\mathrm{z}}$ Values followed by the same letter are not significantly different according to Fisher's protected least significant difference (LSD). NS = not significant. symptoms. Incidence refers to percent plants infected based on leaf or pod symptoms. Severity ratings were based on a 0 to 5 scale where $0=$ healthy, no apparent disease symptoms; 1 = flecks reflecting young lesions not yet sporulating, $1.5 \%$ severity midpoint value (SMV); $2=$ a few isolated lesions on the leaf veins or on pods covering about 3 to $6 \%$ of the surface area, $4.5 \%$ SMV; $3=$ several small lesions scattered on the mid- and secondary veins with collapse of surrounding leaf or pod tissue covering about 6 to $12 \%$ of the surface area, $9 \%$ SMV; $4=$ numerous enlarged lesions scattered over the petiole and leaf blade or on pods covering 12 to $25 \%$ of the surface area, $18.5 \% \mathrm{SMV}$; and $5=$ severe necrosis resulting from many large coalesced lesions on more than $25 \%$ of the surface area accompanied by tissue collapse and/or plant death, 37.5\% SMV. Conversion of severity ratings into percent disease severity was accomplished by using the midpoint value attributed to each severity class. Evaluations were made weekly until R7, pod formation stage, and every 2 weeks thereafter until stage R9, physiological maturity (30).

To compare yield among different treatments, all plants in each 1-m section were harvested on 27 and 28 September, and the pods were placed in a paper bag to air dry at ambient temperature in a greenhouse $\left(21\right.$ to $\left.32^{\circ} \mathrm{C}\right)$. One week later, the numbers of total and infected pods were recorded. Total seed weight of healthy and diseased seed from each 1-m section was recorded. At the end of the season, no cover crops were planted and no tillage was performed in the field.

1994 experiment. Tillage treatments were repeated in 1994 in the same field used for the experiment in 1993. The experimental design was similar to the previous year except that plots were established on 16 June perpendicular to those of 1993 , and each plot was $17 \mathrm{~m}$ long and $12 \mathrm{~m}$ wide and was made up of 13 rows. Fertilizer (12-26-10) was preplant broadcast, then incorporated at a rate of $393 \mathrm{~kg} / \mathrm{ha}$. Plots were planted with certified seed of cultivar Horizon on 17 June at a density of 28 plants per $\mathrm{m}$ of row. The field was treated with the preemergence herbicides trifluralin (Treflan 4E, 1.4 liters/ha), EPTC (Eptam, 4.2 liters/ha), and metolachlor (Dual 8E, 0.85 liters/ha). The postemergence herbicides fomesafen (Reflex 2LC, 2.1 liters/ha) and bentazon (Basagran, 1.4 liters/ha) were applied with a nonionic surfactant (Induce, 1.4 liters/ha) to all areas except the main plots, which were handweeded. After germination and before disease appearance, four 1-m sections were designated in each of the four central rows of each plot. These areas were used for weekly evaluations. The evaluation scale and harvest protocol were the same as those used in 1993. The pods from all 
plants in each 1-m section were harvested on 20 to 22 September.

Estimation of plant residue on the field surface. The percentage of plant residues left on the soil surface in each tillage treatment was estimated using a residue tester (Boonslick Industries, Boonville, MO). The tester consists of $15.25 \mathrm{~m}$ of white line with 100 fluorescent-orange tabs spaced at $15-\mathrm{cm}$ intervals. The number of orange tabs with ground residue under their leading edges equals the percent residue cover for that sample. The procedure was repeated three times in randomly selected areas within plots.

Data analysis. Disease progress curves were constructed for infected plants in each tillage treatment each year. The area under the disease progress curves (AUDPC) for incidence and severity were calculated using the trapezoid rule (7). Analysis of variance was performed on disease incidence and severity data, and on AUDPCs (19). Incidence and severity data were pooled from the sections in each plot to calculate a treatment mean. Means were compared using Fisher's protected least significant difference (LSD) (16). Linear regression analyses were used to detect relationships between the percentage of plant residue and disease incidence or severity.

To determine whether infected plants occurred randomly or in a clustered distribution, ordinary runs analysis was performed on each 1-m section within each plot. A run was defined as the number of plants in a continuous succession of diseased (or healthy) plants $(7,10)$. Frequencies of runs of various sample sizes were compared to appropriate tables (10).

\section{RESULTS}

Anthracnose development. In 1993, the first foliar symptoms of bean anthracnose on leaves were detected 26 days after planting (30 June) in all treatments, and differences in disease incidence were not statistically significant (Fig. 1A). Disease incidence based on leaf symptoms in the chisel treatment was significantly greater $(P<0.02)$ than incidence in the rototilled or moldboard plowed treatments from 7 July until the end of the season. Rototilled plots had higher disease incidence than moldboard plowed plots, but the differences were not statistically significant $(P>$ 0.05 ) during the entire growing season.

Disease based on pod symptoms was first detected on 21 July 1993 (Fig. 1B). Tillage treatments could be significantly separated $(P<0.0003)$ based on incidence measured on 12 and 25 August 1993. Disease incidence was significantly greater in chiseled plots than in rototilled plots, and rototilled plots had a significantly higher incidence than did the moldboard plowed plots. In chiseled plots, incidence based on pod symptoms increased from less than $1 \%$ to more than $55 \%$ between 28 July and 25
August 1993. The average temperature varied between 11 and $27^{\circ} \mathrm{C}$, and moderate precipitation occurred throughout the season (Fig. 1C). The chisel treatment had a significantly higher AUDPC than did the other treatments based on incidence or severity on leaves or pods (Table 1). AUDPCs of severity on leaves and pods, and incidence on pods, were higher in the rototilled than in moldboard plowed plots. Disease incidence on harvested pods was highest (52\%) from the chiseled plots and lowest from moldboard plowed plots (Table 1).

In 1994, anthracnose symptoms were first detected in chiseled plots on 5 July, 18 days after planting (Fig. 2A). Anthracnose was detected in the other treatments 2 weeks later. Disease incidence based on leaf symptoms was greater in chiseled plots than in the other treatments. Significant differences were not found until the final evaluation of the leaves on 30 August. The trend was similar when incidence based on pod symptoms was evaluated (Fig. 2B). Between 14 and 22 August, 3 days had precipitation ranging from 20 to $31 \mathrm{~mm} /$ day (Fig. 2C). AUDPCs based on incidence or severity on leaves and/or pods were not significantly different (Table 1). Disease incidence was highest on pods harvested

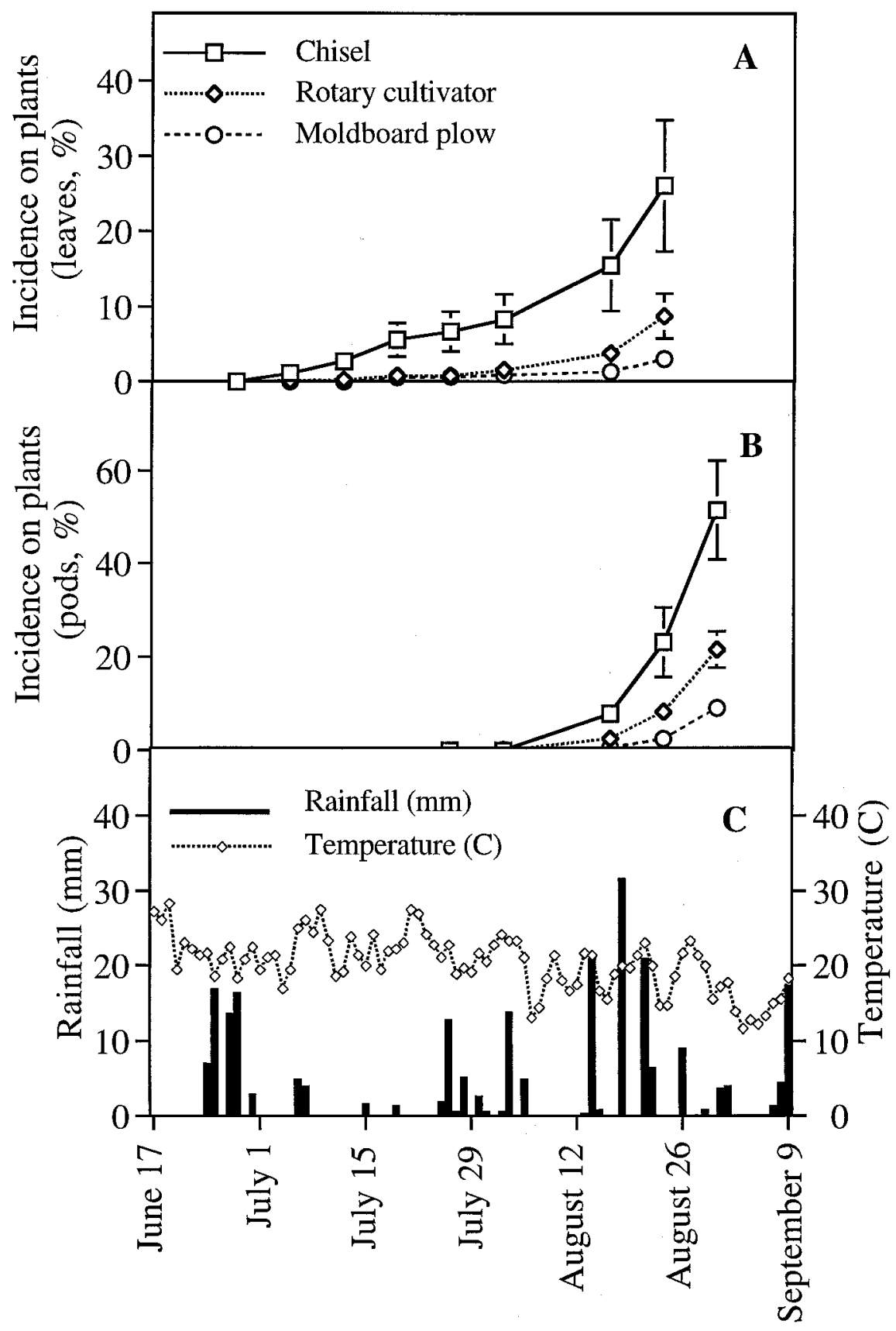

Fig. 2. Disease progress curves of bean anthracnose incidence on whole plants (A) based on leaf symptoms and (B) based on pod symptoms following spring tillage in 1994. Bars represent the standard error of the mean. (C) Daily precipitation and average temperature observed at the experimental site. 
from chiseled plots and lowest from moldboard plowed plots.

Distribution of diseased plants. Ordinary runs analyses were used to evaluate the distribution of diseased plants early and late in the season. Early in the 1993 season, diseased plants in most sections of chiseled plots were randomly distributed (Table 2). Only one section had a clustered distribution of diseased plants. At this time (30 June 1993), plants in seven of 16 sections were symptomless. About 1 month later (28 July 1993), five sections had a clustered distribution of infected plants. Two sections were not infected by that time, whereas nine sections still had random distributions of infected plants. The test failed to determine the pattern of diseased plants in two sections (sections 7 and 8 of row $\mathrm{B}$, that is, $\mathrm{B} 7$ and $\mathrm{B} 8$ ) that had a visible clustered distribution in the field. Similar trends were observed in rototilled and moldboard plowed plots (data not shown). The distribution trends were similar for treatments in 1994 (data not shown). Generally, diseased plants were randomly distributed early in the season and were clustered later in the season.

Table 2. Ordinary runs analysis ${ }^{z}$ of the occurrence and pattern of diseased plants infected with Colletotrichum lindemuthianum in a chiseled plot, replicate 1, in 1993

\begin{tabular}{|c|c|c|c|c|c|c|c|c|}
\hline Row & Section & $m / N$ & $U$ & $E(U)$ & $s(U)$ & $Z_{U}$ & $P$ & Pattern \\
\hline \multicolumn{9}{|c|}{30 June 1993} \\
\hline \multirow[t]{8}{*}{ A } & 1 & $1 / 21$ & 3 & 2.90 & 0.29 & -1.38 & $\ldots$ & $R$ \\
\hline & 2 & $1 / 24$ & 3 & 2.92 & 0.28 & -1.50 & $\ldots$ & $R$ \\
\hline & 3 & $0 / 19$ & 1 & 1 & 0 & & & \\
\hline & 4 & $0 / 20$ & 1 & 1 & 0 & & & \\
\hline & 5 & $1 / 19$ & 3 & 2.89 & 0.31 & -1.26 & & $R$ \\
\hline & 6 & $2 / 25$ & 5 & 4.84 & 0.64 & -0.53 & 0.382 & $R$ \\
\hline & 7 & $1 / 23$ & 3 & 2.91 & 0.28 & -1.46 & $\ldots$ & $R$ \\
\hline & 8 & $4 / 24$ & 3 & 8.67 & 1.27 & -4.07 & 0.000 & $C$ \\
\hline \multirow[t]{8}{*}{ B } & 1 & $0 / 15$ & 1 & 1 & 0 & & & \\
\hline & 2 & $1 / 22$ & 3 & 2.91 & 0.29 & -1.41 & $\ldots$ & $R$ \\
\hline & 3 & $0 / 21$ & 1 & 1 & 0 & & & \\
\hline & 4 & $0 / 18$ & 1 & 1 & 0 & & & \\
\hline & 5 & $0 / 21$ & 1 & 1 & 0 & & & \\
\hline & 6 & $1 / 24$ & 3 & 2.92 & 0.28 & -1.50 & & $R$ \\
\hline & 7 & $7 / 17$ & 6 & 14.1 & 1.74 & -4.37 & 0.080 & $R$ \\
\hline & 8 & $0 / 18$ & 1 & 1 & 0 & & & \\
\hline \multicolumn{9}{|c|}{28 July 1993} \\
\hline \multirow[t]{8}{*}{ A } & 1 & $12 / 21$ & 4 & 11.3 & 2.27 & -3.00 & 0.001 & $C$ \\
\hline & 2 & $5 / 24$ & 9 & 8.92 & 1.54 & -0.27 & 0.394 & $R$ \\
\hline & 3 & $1 / 19$ & 3 & 2.90 & 0.29 & -1.38 & 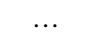 & $R$ \\
\hline & 4 & $2 / 20$ & 3 & 4.60 & 0.70 & -1.57 & 0.105 & $C$ \\
\hline & 5 & $4 / 19$ & 5 & 7.32 & 1.38 & -1.32 & 0.108 & $R$ \\
\hline & 6 & $7 / 25$ & 7 & 11.1 & 1.96 & -1.84 & 0.033 & $C$ \\
\hline & 7 & $4 / 23$ & 5 & 7.61 & 1.30 & -1.62 & 0.053 & $R$ \\
\hline & 8 & $16 / 24$ & 6 & 11.7 & 2.12 & -2.45 & 0.007 & $C$ \\
\hline \multirow[t]{8}{*}{ B } & 1 & $4 / 15$ & 3 & 6.87 & 1.43 & -2.36 & 0.011 & $C$ \\
\hline & 2 & $1 / 22$ & 3 & 2.91 & 0.29 & -1.41 & & $R$ \\
\hline & 3 & $7 / 21$ & 7 & 10.3 & 1.97 & -1.44 & 0.075 & $R$ \\
\hline & 4 & $0 / 18$ & 1 & 1 & 0 & & & \\
\hline & 5 & $0 / 21$ & 1 & 1 & 0 & & & \\
\hline & 6 & $1 / 24$ & 3 & 2.92 & 0.28 & -1.50 & $\ldots$ & $R$ \\
\hline & 7 & $13 / 17$ & 5 & 7.12 & 1.40 & -1.16 & $\ldots$ & $\ldots *$ \\
\hline & 8 & $15 / 18$ & 6 & 6.0 & 1.08 & -0.46 & $\ldots$ & $\ldots{ }^{*}$ \\
\hline
\end{tabular}

${ }^{\mathrm{z}}$ The pattern $R$ is random and $C$ is clustered; $m$ and $N$ are the numbers of infected and total plants in a row, respectively; $U$ is the number of observed runs; $E(U)$ is the expected value of $U, E(U)=1+$ $2 m(N-m) / N ; s(U)$ is the standard deviation of $U, s(U)=\left\{2 m(N-m)[2 m(N-m)-N] /\left[N^{2}(N-\right.\right.$ 1)] $\}^{1 / 2}$; and $Z_{U}$ is the standardized normal test of $U$, which is equal to $-Z_{U L}$ if $U$ is less than $E(U)$ and to $Z_{U R}$ if $U$ is greater than $E(U) . Z_{U L}=[U+0.5-E(U)] / s(U)$ and $Z_{U R}=[U-0.5-E(U)] / s(U)$. $P$ is the cumulative left-tail probability from minus infinity to the value of $-Z_{U}$. Asterisks (*) represent nondefined probability and pattern.
Relationship between anthracnose incidence or severity in the field and anthracnose incidence on harvested pods. In 1993, significant relationships were observed between anthracnose incidence or severity based on leaf and pod symptoms and the percentage of diseased pods after harvest (Table 3). The coefficients of determination $\left(r^{2}\right)$, which represent the amount of variability in the harvested diseased pods attributed to bean anthracnose on leaves, were 0.96 and 0.94 for incidence and severity, respectively. All intercept values were not significantly different from 0 except for incidence on harvested pods versus incidence on pods in the field. In 1994, $r^{2}$ values ranged from 0.75 to 0.93 . Contrary to 1993 , all intercept values were highly significant except incidence on harvested pods versus incidence on pods in the field. In both years, all slopes were significantly different from $0(P=0.0001)$.

Effect of tillage practices on yield. The influence of tillage practices on yield was variable in the 2 years of the study. There were no significant differences in yield among treatments in 1993 or 1994 .

\section{DISCUSSION}

Although bean anthracnose caused by $C$. lindemuthianum was observed on plants in all tillage treatments, the amount of anthracnose development was significantly influenced by the method of spring tillage. Plants in moldboard plowed plots developed significantly less disease than did those in chiseled plots. Similar results have been obtained with other pathogens. Moldboard plowing significantly reduced disease incidence of Cephalosporium stripe in continuous wheat production relative to chisel and no-till $(5,6)$. Sutton and Vyn (22) found that tan spot incidence increased in wheat under minimum or zero tillage compared with wheat under conventional tillage (moldboard plow). Deep plowing has long been recommended for controlling Sclerotium rolfsii in subtropical and tropical climates (21). Deep plowing buries sclerotia and moves the energy source for the pathogen away from stems and crown (18).

In our study, bean anthracnose developed in a trial established in a field that was infested with $C$. lindemuthianum the previous growing season. These results confirm those of previous research that $C$. lindemuthianum can overwinter in bean debris in New York State and initiate anthracnose epidemics in bean fields the following seasons (9). In a study conducted in Canada, however, infested fields were plowed and disked in the fall, and C. lindemuthianum was not detected in the bean crop throughout the growing season on sites that had heavily infected crops the previous year (25). The difference between our results and those obtained in Canada may be because fields in Canada were plowed in autumn. In New York, dry beans 
are planted in May and June and are harvested in September and October. Because of wet conditions that occur in autumn, dry bean producers usually delay incorporation of bean residue until spring. Therefore, bean debris infested with $C$. lindemuthianum remaining on the soil surface may serve as a reservoir of inoculum for the following growing season. Fall plowing with a moldboard would give a long period of plant residue burial, promote microbial decay of the infested debris, and lead to lower disease incidence in the field during the subsequent growing season. Crop residue management, especially fall residue incorporation, may be potential control measures for bean anthracnose in New York. To minimize the risk of soil erosion, fall tillage in fields of early-harvested bean crops could be followed by a cover crop.

The prevailing weather conditions at the experimental site played an important role in the progression of the disease in 1993 and 1994. Anthracnose infection is favored by temperatures between 13 and $26^{\circ} \mathrm{C}$ (28), and the temperatures observed in the field for the growing season were favorable for disease development. However, relative humidity of more than $92 \%$ or free moisture is required during all stages of conidium germination, infection, and subsequent sporulation $(24,31)$; and moderate rainfall at frequent intervals, particularly when accompanied by wind or splashing rain, is essential for local dissemination of conidia and for development of severe anthracnose epidemics (31). These conditions were infrequent during the growing seasons in 1993 and 1994. For instance, there were only 6 days in 1993 with an average relative humidity greater than $92 \%$, and two of them occurred in June before disease appeared in the field. Moderate precipitation (usually less than $10 \mathrm{~mm}$ of daily rain) occurred throughout the season. Lower rainfall and humidity resulted in less anthracnose development than has been observed in high-moisture seasons in New York.

The usefulness of ordinary runs analysis is based on Vanderplank's (29) postulate that clusters of infected plants indicate that inoculum is clumped in the soil (12) or that plant-to-plant spread has occurred, provided that individual samples lie within homogenous areas. A random pattern of diseased plants would be indicative of no or insignificant spread from one plant to an adjacent plant at the time of observation, but it does not necessarily indicate the source of inoculum. The source may be exogenous or the pathogen may be seedborne (13). In this study, since certified seeds produced in an arid climate were used, the field was isolated from other bean fields, and the field was infested with a significant population of $C$. lindemuthianum the previous year, we concluded that initial inoculum originated in bean debris

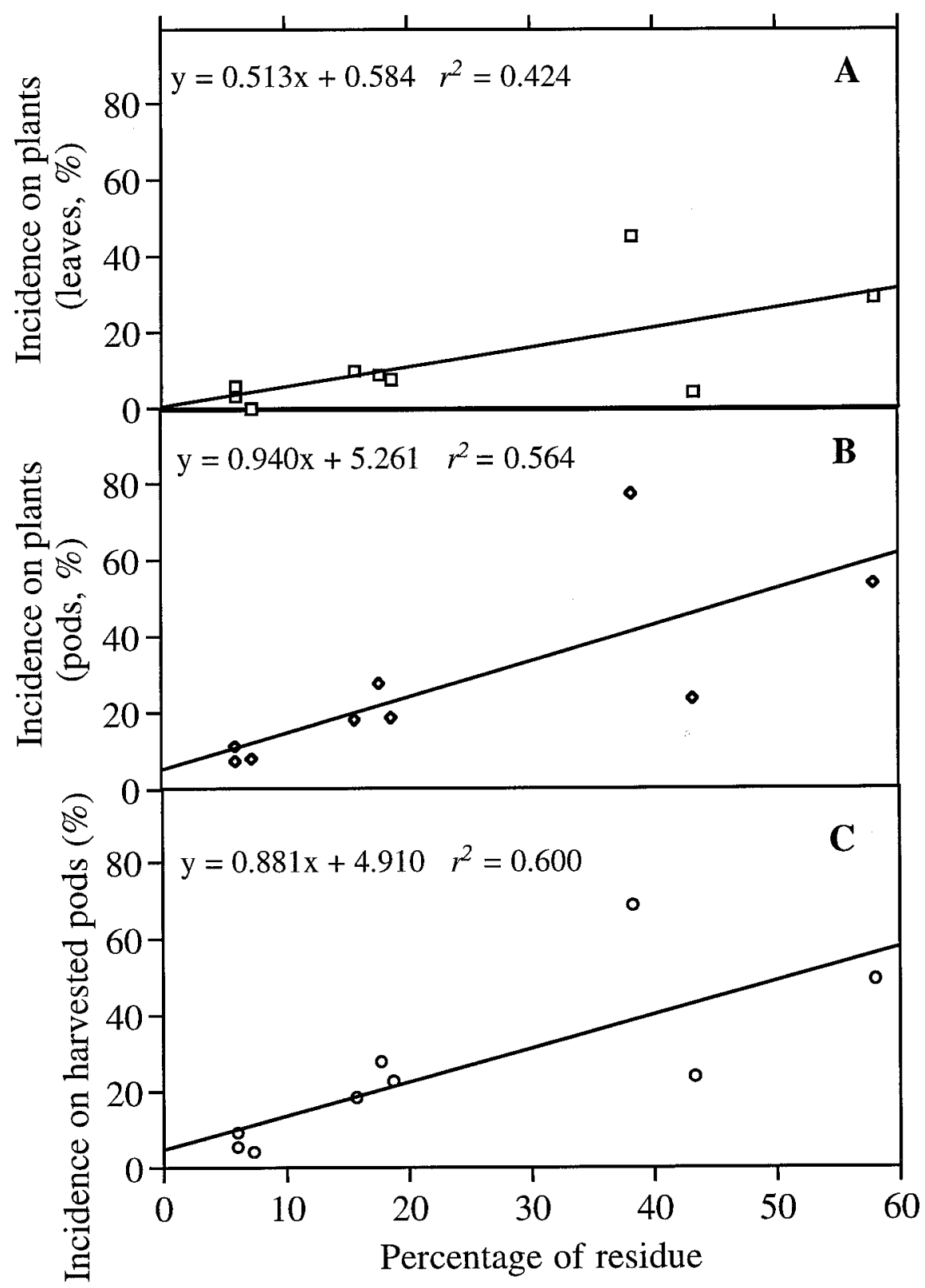

Fig. 3. Relationship between the percentage of residue left on the soil surface after three tillage practices and bean anthracnose incidence on (A) whole plants based on leaf symptoms, (B) whole plants based on pod symptoms prior to harvest, and (C) harvested pods in 1994.

Table 3. Linear regression parameters for relationships between anthracnose incidence or severity on whole plants based on leaf or pod symptoms, and anthracnose incidence on harvested pods in 1993 and 1994

\begin{tabular}{llcrrrrr}
\hline Year & Dependent vs. independent variable & $\boldsymbol{r}^{\mathbf{2}}$ & Slope & & $\boldsymbol{P}$ slope>0 & Intercept & $\boldsymbol{P}$ intercept>0 \\
\hline 1993 & Incidence on harvested pods vs. incidence on leaves & 0.96 & 0.81 & & 0.0001 & 0.71 & 0.6827 \\
& Incidence on harvested pods vs. severity on leaves & 0.94 & 16.50 & & 0.0001 & 1.47 & 0.4540 \\
& Incidence on harvested pods vs. incidence on pods & 0.97 & 0.82 & 0.0001 & -7.70 & 0.0004 \\
& Incidence on harvested pods vs. severity on pods & 0.92 & 6.95 & 0.0001 & -0.34 & 0.8855 \\
1994 & Incidence on harvested pods vs. incidence on leaves & 0.88 & 1.32 & 0.0001 & 9.39 & 0.0015 \\
& Incidence on harvested pods vs. severity on leaves & 0.75 & 2.44 & 0.0001 & 12.67 & 0.0017 \\
& Incidence on harvested pods vs. incidence on pods & 0.93 & 0.90 & 0.0001 & 1.34 & 0.5703 \\
& Incidence on harvested pods vs. severity on pods & 0.88 & 6.17 & 0.0001 & 9.36 & 0.0013 \\
\hline
\end{tabular}


from the previous year. The data from the ordinary runs analysis showed that early in the season, diseased plants were randomly distributed. Later in the season, many sections developed a clustered distribution of infected plants. However, the test could not detect the departure from randomness of some sections, although they had an obvious clustered distribution of diseased plants. A similar problem was noted by Madden et al. (13), where some sections progressed from random to clustered and then back to random even when a significant aggregation of diseased plants was detected.

Tests for determining the pattern of diseased plants in a row have produced different results (13), especially at high levels of disease incidence. The data for analysis consist of an ordered sequence of two types of symbols (diseased or healthy plants): $m$, representing the number of diseased plants in a row, is always of type 1 ; and $N-m$, the number of healthy plants, is of type 2 . To obtain the appropriate significance level from the table of probabilities, the smaller number of symbols, whether $m$ or $N-m$, should always be labeled type 1 (10). Therefore, when $m$ is large (greater than $N-m$ ), the type 1 symbol becomes $N-m$ (healthy plants), and the probability observed is associated with the pattern of healthy plants. Similar observations were made when Madden et al. (13) noticed that the $Z$-statistic decreased as $m$ approached $N$. Small values of $Z$ indicate that one cannot reject the null hypothesis of randomness. This would explain the variable results observed when $m$ is big. In fact, the pattern of the few healthy plants may be either randomly distributed or have a clustered distribution. Unfortunately, it is impossible to infer the pattern of the many diseased plants from the pattern of healthy ones. Therefore, ordinary runs analysis is most valuable and provides consistent results when it is used for $m$ less than $N-m$, which is early in the season, before many plants become infected.

From the results of this work and previous research, the recommendations for bean anthracnose control in New York emphasize a minimum 2-year rotation from beans, deep plowing of bean residue (preferably in the fall), and the use of certified bean seed produced in an arid climate $(9,26)$.

\section{LITERATURE CITED}

1. Allen, D. J. 1983. The Pathology of Tropical Food Legumes. Disease Resistance in Crop Improvement. John Wiley \& Sons, Chichester, England.

2. Anonymous. 1994. New York Agricultural Statistics 1993-1994. New York Agricultural Statistics Service, Albany, NY.

3. Arraya Fernandez, C. M., Dhingra, O. D., and Kushalappa, A. C. 1987. Influence of primary inoculum on bean anthracnose prevalence. Seed Sci. Technol. 15:45-54.

4. Barrus, M. F. 1921. Bean anthracnose. Cornell Univ. Agric. Exp. Stn. Mem. 42:101215 .

5. Bockus, W. W., and Claassen, M. M. 1992. Effects of crop rotation and residue management practices on severity of tan spot of winter wheat. Plant Dis. 76:633-636.

6. Bockus, W. W., O'Connor, J. P., and Raymond, P. J. 1983. Effect of residue management method on incidence of Cephalosporium stripe under continuous winter wheat production. Plant Dis. 67:1323-1324.

7. Campbell, C. L., and Madden, L. V. 1990. Introduction to Plant Disease Epidemiology. John Wiley \& Sons, New York.

8. Campbell, C. L., and Noe, J. P. 1985. The spatial analysis of soilborne pathogens and root diseases. Annu. Rev. Phytopathol. 23:129-148.

9. Dillard, H. R., and Cobb, A. C. 1993. Survival of Colletotrichum lindemuthianum in bean debris in New York State. Plant Dis. 77:1233-1238.

10. Gibbons, J. D. 1976. Nonparametric Methods for Quantitative Analysis. Holt, Rinehart, and Winston, New York.

11. Hirst, J. M., and Stedman, O. J. 1963. Dry liberation of fungus spores by raindrops. J. Gen. Microbiol. 33:335-344.

12. Jeger, M. J., Kenerley, C. M., Gerik, T. J., and Koch, D. O. 1987. Spatial dynamics of Phymatotrichum root rot in row crops in the Blackland region of north central Texas. Phytopathology 77:1647-1656.

13. Madden, L. V., Louie, R., Abt, J. J., and Knoke, J. K. 1982. Evaluation of tests for randomness of infected plants. Phytopathology 72:195-198.

14. Maloy, O. C. 1993. Plant Disease Control. Principles and Practice. John Wiley \& Sons, New York.

15. Ntahimpera, N., Dillard, H. R., Cobb, A. C., and Seem, R. C. 1994. Bean anthracnose development in different tillage practices. (Abstr.) Phytopathology 84:1374.

16. Ott, L. 1988. An Introduction to Statistical Methods and Data Analysis. 3rd ed. PWSKent, Boston, MA.

17. Pastor-Corrales, M. A., and Tu, J. C. 1989.
Anthracnose. Pages 77-104 in: Bean Production Problems in the Tropics. 2nd ed. H. F. Schwartz and M. A. Pastor-Corrales, eds. Centro Internacional de Agricultura Tropical (CIAT), Cali, Colombia.

18. Punja, Z. K., Carter, J. D., Campbell, G. M., and Rossell, E. L. 1986. Effects of calcium and nitrogen fertilizers, fungicides, and tillage practices on incidence of Sclerotium rolfsii on processing carrots. Plant Dis. 70:819-824.

19. SAS Institute. 1985. SAS User's Guide: Statistics. Version 5 ed. SAS Institute, Cary, NC.

20. Sumner, D. R., Doupnik, B., Jr., Boosalis, M. G. 1981. Effects of reduced tillage and multiple cropping on plant diseases. Annu. Rev. Phytopathol. 19:167-187.

21. Sumner, D. R., Threadgill, E. D., Smittle, D. A., Phatak, S. C., and Johnson, A. W. 1986. Conservation tillage and vegetable diseases. Plant Dis. 70:906-911.

22. Sutton, J. C., and Vyn, T. J. 1990. Crop sequences and tillage practices in relation to diseases of winter wheat in Ontario. Can. J. Plant Pathol. 12:358-368

23. Tochinai, Y., and Sawada, K. 1952. Observation on the overwintering of the bean anthracnose fungus, Colletotrichum lindemuthianum Briosi et Cavara. Hokkaido Univ. Fac. Agric. Mem. 1:103-112.

24. Tu, J. C. 1982. Effect of temperature on incidence and severity of anthracnose on white beans. Plant. Dis. 66:781-783.

25. Tu, J. C. 1983. Epidemiology of anthracnose caused by Colletotrichum lindemuthianum on white bean (Phaseolus vulgaris) in southern Ontario: Survival of the pathogen. Plant Dis. 67:402-404.

26. Tu, J. C. 1988. Control of bean anthracnose caused by delta and lambda races of Colletotrichum lindemuthianum in Canada. Plant Dis. 72:5-8.

27. Tu, J. C. 1992. Colletotrichum lindemuthianum on bean: Population dynamics of the pathogen and breeding for resistance. Pages 203-224 in: Colletotrichum: Biology, Pathology and Control. J. A. Bailey and M. J. Jeger, eds. C.A.B. International, Wallingford, UK

28. Tu, J. C., and Aylesworth, J. W. 1980. An effective method of screening white (pea) bean seedlings (Phaseolus vulgaris L.) for resistance to Colletotrichum lindemuthianum. Phytopathol. Z. 99:131-137.

29. Vanderplank, J. E. 1946. A method for estimating the number of random groups of adjacent diseased plants in a homogenous field. Trans. R. Soc. S. Afr. 31:269-278.

30. van Schoonhoven, A., and Pastor-Corrales, M. A. 1987. Standard System for the Evaluation of Bean Germplasm. Centro Internacional de Agricultura Tropical (CIAT), Cali, Colombia.

31. Zaumeyer, W. J., and Thomas, H. R. 1957. A monographic study of bean diseases and methods for their control. U.S. Dep. Agric. Tech. Bull. 868. Rev. 